\title{
TO REVIVE AN ABUNDANT LIFE: Catholic Science and Neoextractivist Politics in Peru's Mantaro Valley
}

\author{
STEFANIE GRAETER \\ Northwestern University \\ (D) http:/ / orcid.org/0000-0001-5689-4101
}

I did not expect to see a scientific laboratory in the highland city of Huancayo, let alone at the offices of its archbishop. In the crisp morning air of a midSeptember day in 2010, I awaited the sight of more desks, file cabinets, binders, and manila envelopes (the stuff of NGOs) as my guide deftly unfastened the three stiff locks of an iron-wrought door. Yet when the door swung open, the room revealed an entirely different menagerie of objects. In the entranceway lay bulky pieces of air-monitoring equipment, scattered among coolers chock-full of plastic bottles. On top of black countertops, boxed rubber gloves neighbored bottles of ethanol, their red nozzles poised at right angles awaiting surfaces to disinfect. In my line of sight stood a heat-sanitizing drying rack, a vacuum-hooded counter space, and the cascading pages of safety warnings fastened to the wall. In a corner, a few too many lab coats overwhelmed a standing hanger, unfit for its task. Although no one thing makes a lab a lab, at that moment I knew I knew a lab when I saw one.

This article analyzes the integration of religious and scientific practitioners and practices within a Catholic knowledge-making project called El Proyecto Mantaro Revive (Revive the Mantaro Project). ${ }^{1}$ It was this project's lab that I encountered locked away behind a maze of offices and garden courtyards in an old missionary complex. I had just arrived by overnight bus from Lima to visit Mantaro Revive's organizers in Huancayo, the metropolitan hub of the Mantaro 
Valley and capital of the Central Andean Junín region. I knew little about Mantaro Revive at the time, only that it was connected to a transnational network of organizations campaigning against lead contamination in the nearby city of La Oroya. La Oroya is perhaps the most infamous case of contamination caused by mining operations in Peru. The city's enormous smelter, built in 1922 to refine mineral sludge from nearby mines owned by the U.S.-based Cerro de Pasco Corporation, rapidly transformed La Oroya's mountainous terrain into a stark, white moonscape. The Yauli and Mantaro Rivers, which intersect at the city's center, became turbid, sepia tributaries deprived of the migrating trout that once populated them.

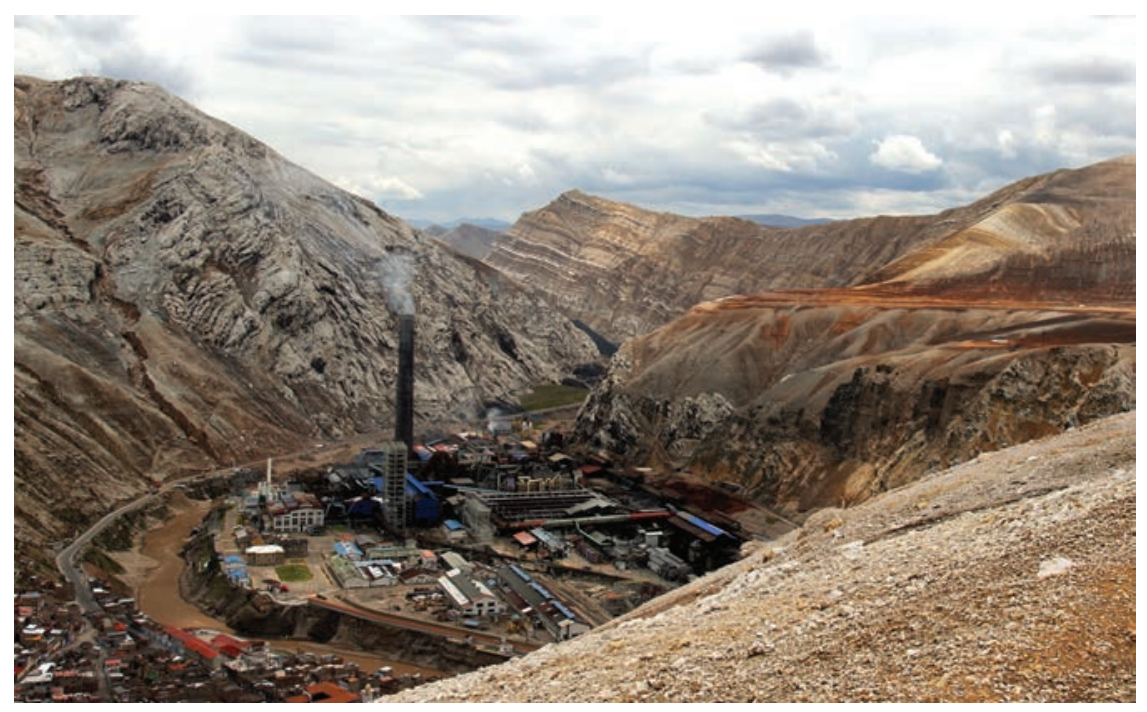

Figure 1. The metallurgic complex at La Oroya. Photo by Stefanie Graeter.

In the late 1990s, the city also became central to a national debate over the human cost of an extraction-based economy. While the smelter's smoke led to obvious agricultural blight (Mallon 1983), its impact on residents remained largely undisclosed until 1999, when Peru's Ministry of Health (MINSA) measured lead levels in La Oroya's residents up to eight times higher than international safety thresholds (Villena Chávez 1999). This triggered a series of studies by NGOs, USAID, and the U.S. company Doe Run, who purchased the smelter in 1997, all of which revealed very high human lead levels in La Oroya. Concern multiplied in transnational advocacy circles about the potentially severe cognitive harm of lead, especially for exposed children. Meanwhile, Doe Run's environmental rec- 
ord grew ever more bleak: pollution worsened and extensions for promised technological upgrades to reduce emissions were repeatedly sought from Peru's Congress and granted. Nonetheless, by keeping the local economy humming and implementing much-needed social programs (alongside suspected bribery of state officials), Doe Run managed to prevent the lead studies from garnering much political influence. In 2009, however, the smelter shut down on dubious financial and legal grounds related to the 2008 economic crisis but also connected to the company's increasingly scandalous reputation. In 2012 company supporters mounted new plans to reopen the smelter without solving La Oroya's pollution problems first. This pending decision also manifested a persistent societal disagreement in Peru: does the national economy require bodies with minerals?

Mantaro Revive's scientific documentation of heavy-metal contamination in the Mantaro Valley existed as a political response to this fundamental disagreement over the governance of life and death in Peru. In 2004, the project's founders authored what became the most cited scientific study of human lead exposure in La Oroya, which spurred a scientific enterprise that operated until 2013. Alongside scientific measurements, members of Mantaro Revive held policy workshops in urban centers and remote hamlets, sustained health programs in La Oroya, and attended political events in Lima. Throughout these activities, the project's own scientific evidence formed the epistemic basis of its political advocacy.

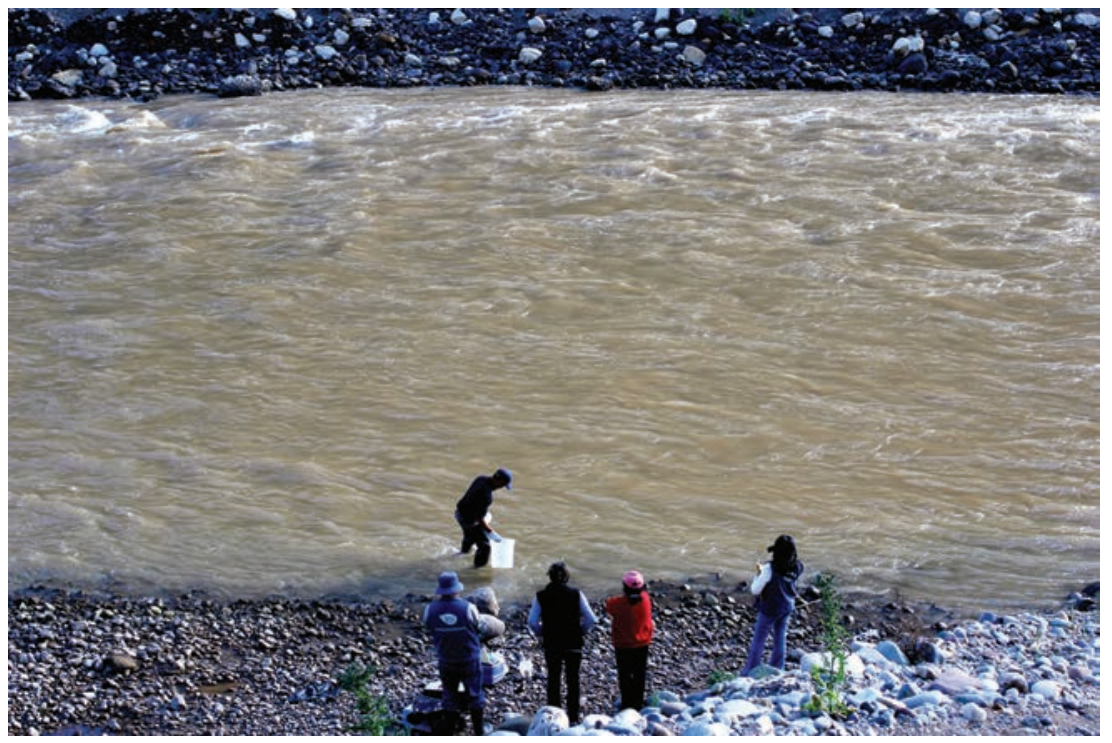

Figure 2. Members of the Mantaro Revive Project sample the Mantaro River near La Oroya. Photo by Stefanie Graeter. 


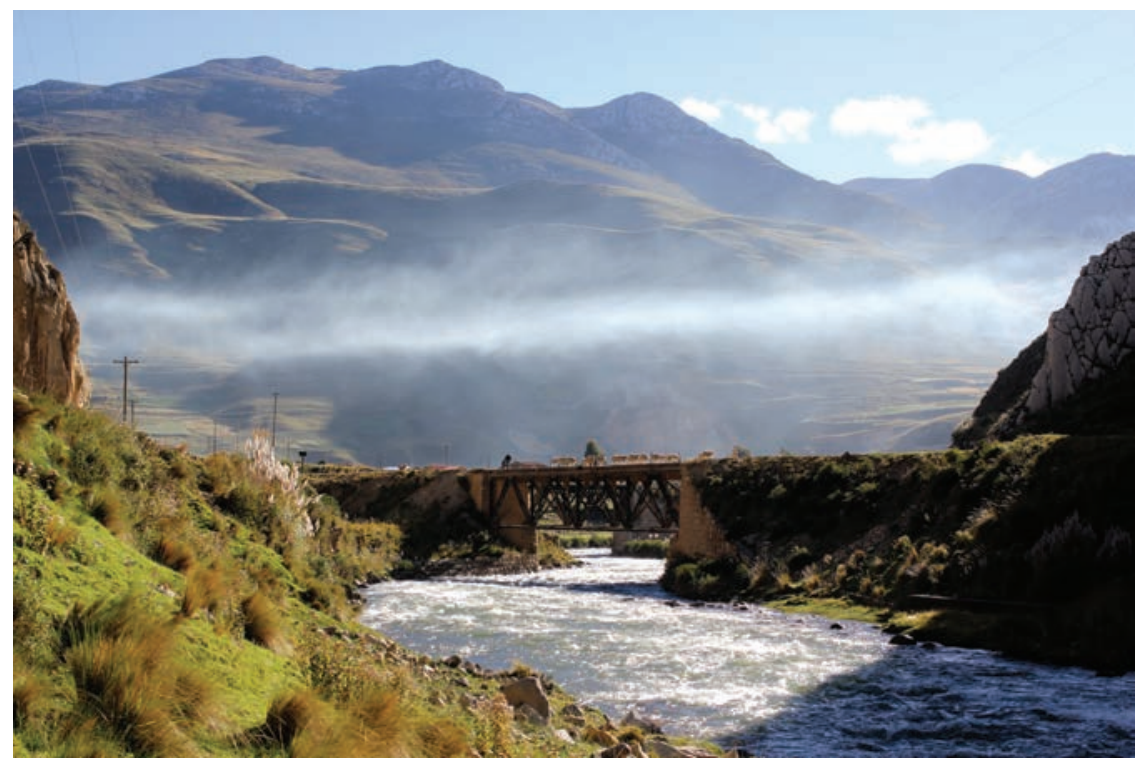

Figure 3. Farmland alongside the Yauli River, a short distance from La Oroya. Photo by Stefanie Graeter.

How did the Catholic Church become such an apt institution for the production of toxicological science in Peru? Seeking to understand this question ethnographically, I undertook fieldwork with Mantaro Revive, mostly in 2012, as part of a broader research project on lead exposure and mining politics conducted in Peru over twenty months between 2010 and 2015. Perhaps surprisingly, a comparative analysis of science and religion did not result from this fieldwork. While in a U.S. epistemic context science and religion are often diametrically opposed, ${ }^{2}$ my interlocutors in Peru dwelled little on potential incongruities. Ethnographic engagement with Catholic scientists led me to put the categories of "science" and "religion" aside and to focus instead on the sociocultural conditions that brought their practitioners into collaboration. For those who cared about lead contamination in La Oroya, this colaboring mattered a great deal: before the Catholic Church's involvement, a “credible," "legitimate," or “objective” lead study did not exist, according to my interlocutors.

In her research with Christian advocates, Candis Callison (2014, 138) calls the process of "re-framing" climate change as a Christian ethical concern a "blessing of the facts." While Mantaro Revive undertook similar acts of translation, this article argues that the project's institutional and ethical affiliations mattered even more for the social and technical legitimacy of its scientific data. As an institutional 
companion to scientific practice, the Catholic Church cloaked its data in trust, stabilizing the ethical uncertainty held against other, potentially corrupted sources of scientific knowledge. In turn, science, a potentially efficacious political tool, provided a field of practice to enact a Catholic ethos of life that could revive the Mantaro Valley, as the name of the project suggests. Therefore, for the purposes of this article, Catholic science refers to knowledge-making practices imbricated with the ethics of the Catholic Church and its practitioners. Like corporate science, university science, or lay science, institutional links to the production of knowledge carry both general and specific cultural meaning. The point is not to claim that all Catholic science has inherently better ethics, but rather that the knowledge practices of this archdiocese took on a situated objectivity in a sphere of politics specific to its time and place.

The achievement of objectivity, a collective agreement on the credibility of knowledge, generates conditions of political actionability - the ability to act on knowledge politically. Such epistemic politics within ecological controversies oblige an ethnographic attunement to the sociocultural conditions through which situated objectivities come into existence within localized knowledge-making projects. This extension of Donna Haraway's (1988) notion of "situated knowledges" orients us to the on-the-ground, localized pragmatics of producing politically actionable knowledge. The achievement of scientific objectivity is not a solely technical undertaking. Mantaro Revive's scientific practices demonstrate the complex arrangement of actors and institutions required to achieve a socially recognized objectivity. In the sections that follow, I conceptualize the situated production of politically actionable knowledge in the Mantaro Valley as a process of accompaniment, a walking-with that provides scientific practices with moral credibility and trust. Ethnographically detailing the achievements and failures of scientific/political projects reveals how social relations shape the production and destiny of knowledge, which in environmental politics contour ecological distributions of pain, pleasure, possibility, and ultimately life itself. Here, Mantaro Revive's pursuit of politically legitimate scientific evidence achieved tangible policy measures. Yet beyond measures of efficacy or failure, this essay argues that within a state of ubiquitous corruption and legal dysfunction, Mantaro Revive's work must also be understood as the production of a biopolitical "dissensus" (Rancière 2004, 304). Its scientific politics asserted the "biolegitimacy" (Fassin 2009,49 ) of life desecrated by the mineral industry through enactments of democratic governance, human rights, and lived abundance within a social world where such conditions do not function or exist. 


\section{THE NOXIOUS ASH OF NEOEXTRACTIVISM}

On February 22, 2012, crowds of devotees packed the high-steeped nave of Huancayo's cathedral. Their numbers did little to warm the icy air; few had space to sit or lean, but all listened attentively to the archbishop's thundering oration of Ash Wednesday service. As I arrived and stood in the back with members of Mantaro Revive, Monsignor Barreto's liturgy spoke to the very soil we had just left behind in the lab. Barreto expounded to his congregation: "Since [the smelter's] closure in 2009, we have seen levels of sulfur dioxide and lead in the air of La Oroya reduce by 99 percent. Levels of lead in the children of La Oroya have also dropped." His words drew from Mantaro Revive's longitudinal data, compared to recent studies by MINSA, to reflect on the pending decision by Congress to reopen the smelter. While the pollution reductions were "good news," he denounced congressmen from Junín for authoring a new law to extend the company's environmental upgrades for another thirty months: "We as the church cannot support this; there cannot be social inclusion without the right to health.”

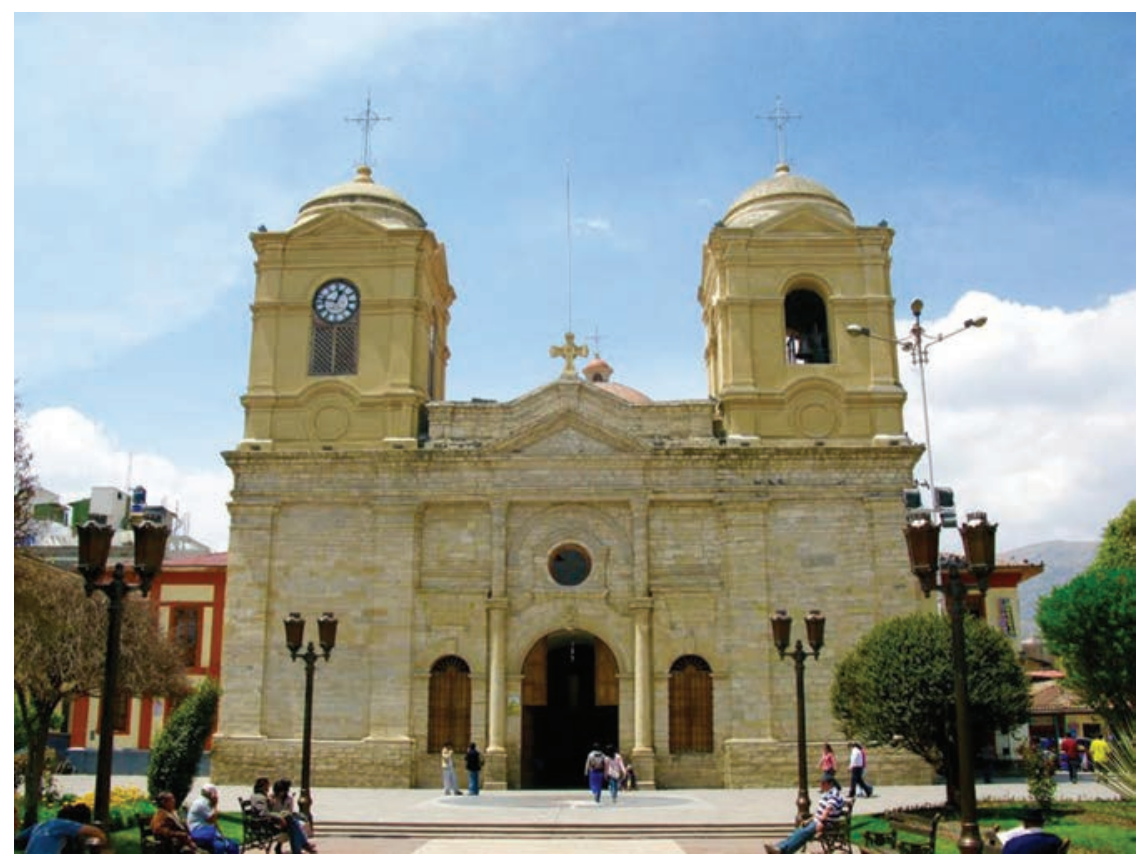

Figure 4. The Cathedral of Huancayo. Photo by Stefanie Graeter. 
As the service ended, people filed to the pulpit and exited the cathedral with their foreheads marked with a cross of ash. Departing too, I crossed paths with Melinda Gonzales, the chemical engineer who first showed me Mantaro Revive's lab. We discussed the monsignor's mention of La Oroya, and Melinda mused that as Ash Wednesday initiated a period of spiritual reflection, it made an apt moment for Barreto to discuss La Oroya with his congregation. The monsignor's intervention had not been unusual; for years he had used his pulpit to "defend the right of life" (defender el derecho a la vida). We parted ways and I walked over the cobblestoned road to my hotel, adjacent to the archbishopric. As I entered the glass doorway of Los Balcones, I reflected further on the symbolic resonances of the ritual marking of ash, the soil samples in the lab, and Barreto's reference to La Oroya. Ash reminds the faithful of the dust from which they come and to which they will inevitably return. Its mark recalls life's swift gasp between states of earthly matter, the precious brevity of creation - a truth often too painful to recollect. Likewise, by remembering La Oroya in their cathedral and laboratory, Barreto and Mantaro Revive enunciated another oft-forgotten truth: the desacralization of life by the national tradition of metal production.

Since the 1990s, new configurations of antimining and environmental politics have arisen in response to the rapid transnationalization and growth of Peru's extractive industries. These extractivist-resistance projects are complex and heterogeneous, including actors such as indigenous groups; campesinos; water, lagoons, mountains, and animals; Apus, ${ }^{3}$ shamans, and earth beings (de la Cadena 2015); local, national, and transnational NGOs and missionary networks; politicians; local and foreign scientists; and so on (see Li 2015; de la Cadena 2010, 2015; Stensrud 2016). Within the layered networks of these political projects, religious figures, particularly Catholic priests, occupy central nodes of leadership, social legitimacy, and ethical translation. As its laboratory so quickly clarified, however, Mantaro Revive did not just operate a faith-based advocacy group but also ran a scientific research program that epistemically anchored its politics.

Mining in the Andes is nothing new: it predates the colonial encounter, fueled European imperialism for centuries, and has since gone through several postcolonial iterations (Nash 1979; Taussig 1980; Mallon 1983). In Latin America, scales of extraction have multiplied under neoextractivisms, which the Argentine scholar Maristella Svampa (2015) describes as a process of dispossession impelling national economies (with seeming inevitability) to focus on raw, nonrenewable 
exports, extracted and brokered by enormous foreign corporations at a colossal physical scale. After decades of civil war and economic turmoil, in the late 1990s President-cum-dictator Alberto Fujimori initiated Peruvian neoextractivism - privatizing older, then-nationalized infrastructure like La Oroya's smelter and facilitating new prospecting and investments, alongside greater neoliberal reforms. Known colloquially as "Fuji-shock," his policies correlate with many positive economic indicators: a growth rate of 6.1 percent, more than double the regional average, and reductions in the poverty rate from 55 to 24 percent between 2002 and 2013. During this period, the twenty-fivefold increase in mining investments stood for many as the "background boom" (Republica 2011) of this economic growth. The industry accounts for roughly 64 percent of annual exports, and Peru typically ranks among the world's top five producers of zinc, tin, lead, gold, copper, and silver.

Growing voices of dissent have simultaneously arisen to challenge the rationales undergirding Peru's neoextractivist governance. Alternative development analyses, such as that of the Uruguayan social ecologist Eduardo Gudynas (2012, 2014), contend that positive economic indicators belie massive environmental costs, the actual societal redistribution of wealth, and the inherent economic instability of an industry dependent on fluctuating global demand. The debated economics of open-pit mining, as well as their unfathomable disturbances to local socionatural worlds - whose craters can span hundreds of square kilometershave, as Fabiana Li (2015) points out, unearthed not only metals but also much conflict. In 2015, the Defensoría del Pueblo (2016) tallied 174 socioenvironmental conflicts in Peru, 69 percent of its annual count of national social conflicts, of which 113 pertained to proposed or ongoing mineral extraction. ${ }^{4}$

In Latin American contexts and beyond, anthropologists and other scholars describe how impacted communities and social movements respond to harsh labor conditions, fluctuating prosperity, colossal environmental impacts, and the contentious health repercussions of extractive industries, often referred to as the resource curse (Sawyer 2004; Bebbington et al. 2008; Welker 2014; Kirsch 2014; Lyons 2016). Socioenvironmental conflicts in Peru manifest in formations familiar to many kinds of Latin American social movements - organized protests, media campaigns, blockades, and violent state repression - but also increasingly through scientific proof of chemical contamination. Scientific activism responds to the centrality of technical expertise to state-industry practices that legitimize megamining projects (Gudynas 2014). For instance, the state requires Environmental Impact Assessments (EIAs) of new projects to document potential risks and to 
suggest methods to manage them. As Fabiana Li $(2015,186)$ argues, EIAs formalize accountability, but they also "prioritize mining interests and enable corporations to define the standards of performance that governments will use to establish compliance" (cf. Welker 2009).

Alternative scientific projects demand new forms of ethical reckoning and accountability. The potential power of their articulations relies on mirroring a state-industry technoscientific vernacular, while divulging biopolitical mappings of the chemical excesses of extraction absorbed by human populations and their life-sustaining ecologies. They do not map the productive "make live" of Michel Foucault's $(2003$, 254) definition of biopower, but instead divulge the underside of his well-known axiom, the disposable segments of society to "let die." Scientifically representing bodies with minerals points to the corporeal externalities misrepresented by documents like the EIA, which ethically sanction mining projects. These alternative knowledge-making enterprises thus subvert the biopolitical logics and technical expertise that normalize distributed chemical exposures as an at times unfortunate, but necessary, material reality of an extractive economy.

Exposure studies, however, only quantify; significant ethico-political work is necessary to make measurements actionable within a sociopolitical field of practice. Thus scholarship on toxicity and environmental (in)justice often describes how scientific credibility corrodes and lay or nonscientific facts fail to achieve political clout when their data confer blame on a resistant industry or on state actors (Brown 1992; Fortun 2001; Murphy 2006; Auyero and Swistun 2007; Lora-Wainwright 2013; Shapiro 2015). While Mantaro Revive's story illustrates the disintegration of scientific authority in the Mantaro Valley, it also reveals how the project's practitioners reinvigorated scientific expertise within an antagonistic social field that their venture nonetheless wished to impact. To remind the national polity of neoextractivism's noxious dust, members of Mantaro Revive enacted practices of science and Catholicism, which, I argue, simultaneously authorized their technical and political legitimacy.

\section{FROM TRUTH TO KNOWLEDGE: Science in the Defense of an}

\section{Abundant Life}

A thief comes only to steal and slaughter and destroy; I came so that they might have life and have it more abundantly. 
I joined Mantaro Revive as an ethnographer in 2012. My participation in the roughly thirty-person project-from preparing soil samples to attending health workshops in La Oroya — was exclusively coordinated by Juana Jiménez, the project's director and chemical engineer, often simply referred to as la ingeniera (the engineer). La ingeniera was also a devout Catholic. Of steely demeanor, Jiménez invariably kept her hair cut very short and wore all black beneath Mantaro Revive's logoed navy-blue vest. In one of our first meetings, she outlined the project's four-tiered structure on a whiteboard. Team One implemented health and economic programs in La Oroya and gathered data on childhood anemia and lead levels. Team Two, the technical team (Equipo Técnico) — she paused to clarify that all the teams were "technical" - sampled water, air, and soil. Their data fed into Team Three, Public Impact (Incidencia Publica), tasked with communicating their findings to local authorities, whose responses shaped the advocacy of Team Four, which sought policy impact (hence its name, Incidencia Politica) through legal measures.

The project's structure resulted from dialogues within the archbishop's environmental task force, La Mesa de Diálogo Ambiental, after the publication of its 2004 lead-exposure study. While this study established lead's ubiquity in La Oroya, its unexpected outcome pertained to the control population, in Concepción. A small city renowned for its artichoke production, Concepción's relatively pristine environs made it a suitable control to compare with La Oroya. The study revealed, however, that Concepción's residents also had high lead levels in their blood. Revealing indelible linkages between metallurgy and human bodies throughout the region — not just in La Oroya — this first study inspired the creation of a project to "revive" the entire Mantaro Valley. "The dream of the environmental task force of the Junín Region," the introduction to its 2007 scientific report states, "is to make it possible for the Mantaro Basin to once again have life in plenitude [vida en plenitud]; under this premise arose the proposal for the project denominated as 'Revive the Mantaro"” (Mantaro Revive 2007, 1).

The Catholic precept to "defend life" and the secular-humanist "right to life" often articulate the ethico-political stakes of Peruvian antiextractivist politics. Defending life controverts extractivism's vital promises of progress and development, resignifying their forms of life as "emergent forms of death" instead (Lyons 2008). Mantaro Revive, however, saw its work as distinct, though not disconnected, from antiextractivist struggles throughout Peru. Its oft-repeated motto exemplifies the distinction: "If we know our resources, we can transform a protest into a proposal" (Cuando conocemos nuestros recursos, podemos llevar la protesta 


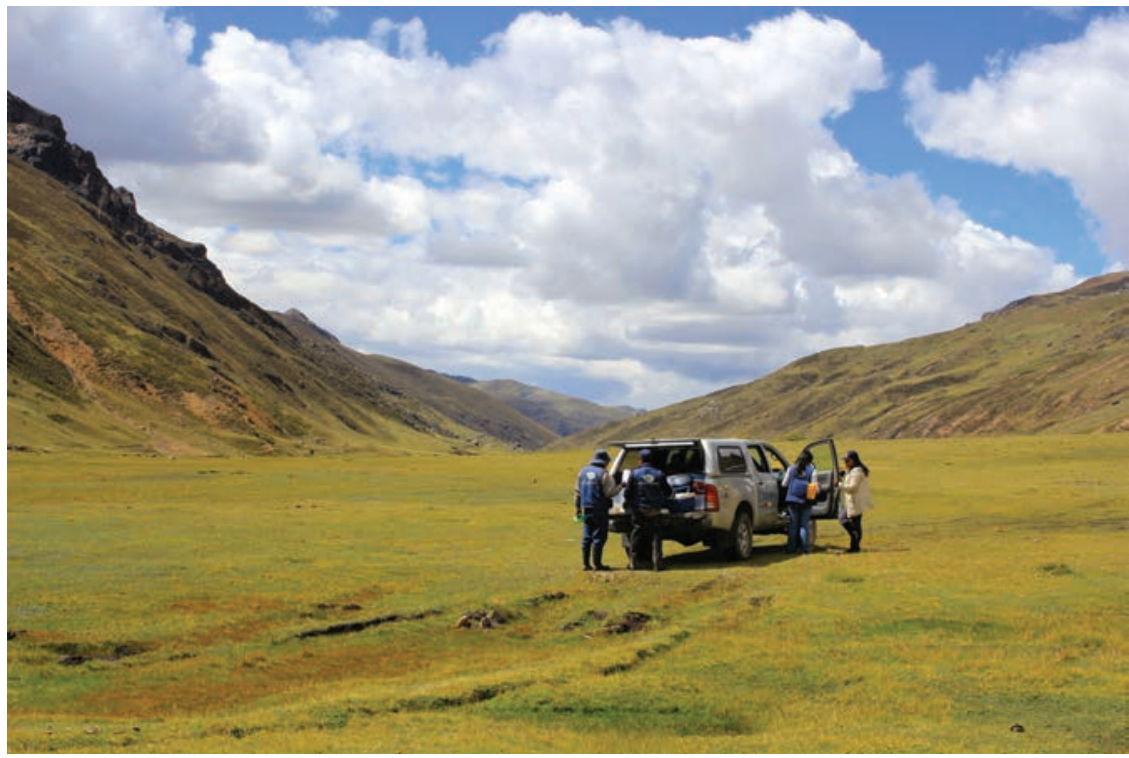

Figure 5. Members of the Mantaro Revive Project prepare to take water samples in an agricultural valley downstream of a mine. Photo by Stefanie Graeter.

hasta la propuesta). To enact its ethics of plenitude, or what Jiménez called "abundance," Mantaro Revive brought its protest against mining's immorality into the laboratory.

The work of several anthropologists highlights humanitarianism's ubiquity in international politics (Nguyen 2004; Ticktin 2006; Fassin 2009). Yet as Talal Asad (2003, 129) argues, despite the universalist ambitions of human rights, their application relies on national judicial institutions for enforcement. Failing to achieve global human rights, international humanitarianism produces what Peter Redfield (2005, 329) calls a politics "focused on survival — a minimalist biopolitics." The isolated physical body, thought to transcend politics, emerges as humanitarianism's primary site of intervention. Despite its discursive dominance, the moral framework of human rights similarly struggles to generate tangible impacts on political decisions about mining and contamination in Peru. At face value, life lived in contamination is still living; bare life (see Agamben 1998) remains intact.

Despite existing regulations, in practice mining companies are given significant license to pollute their surroundings, and little is done to care for those exposed to heavy metals. Referencing this legal informality, numerous people repeated to me the adage, "In Peru there are laws, but no one complies with the 
law!" (En Perú hay ley, pero la ley no se cumple!) Therefore, despite reshaping the public discourse on mining, a sense of futility can accompany protests against suspected legal breaches by industry (Bebbington et al. 2008). Furthermore, national authorities and media publicly dismiss such protests as "just politics"; policy remedies require technical information, not the passion of politics. While governments frequently depoliticize an issue by reducing it to a technical problem outside of democratic processes (Ferguson 1994; Petryna 2002), here it is an explicit government and media practice to delegitimize alternative social projects as merely political. Public appeals for legal compliance, or against the deficiency or insufficiency of current statutes, at a minimum require technoscientific proof that substantiates moral claims of injustice and the infringement of human rights.

Consequently, the Church of Huancayo preferred to do its politics through science: to "know our resources" scientifically, as Mantaro Revive's motto stated. Within a technocratic paradigm of governance, scientific measurements translate purported toxic transgressions directly to legal pollution limits, potentially leading to fines, sanctions, or even company closures. Paradoxically, then, exposure science offered a way to do politics without Politics. Such a political calculus, however, reflects more than just technocratic hegemony. Only two decades after the fall of the Shining Path (Sendero Luminoso), Peru's political left still struggles to redefine itself in the wake of a socialist uprising. Sendero diminished the moral high ground of leftist populism in Peru, including Andean campesino movements, making their political agendas of environmental and social injustice vulnerable to vilification by the right-of-center media and political factions. Relatedly, during the militarized suppression of Sendero in the 1990s, Fujimori dismantled the power of the Catholic Church in the Andes, construed as too close to the rebels' socialist ideology. Previously, Peru housed a growing contingent of liberation theologians, led by Gustavo Gutiérrez (1988), which put structural injustice at the center of its theology. During the war, Juana Jiménez recalled, the Catholic Church grew very conservative (see Schulte-Bockholt 2013). Now, Jiménez thought, with some distance from the "period of violence" and a more liberal era of the Vatican itself, a growing sector of the Peruvian Church was returning "closer to the problems of society." This time, however, rather than fighting from a moral position alone and with greater distance from national leftist politics, Mantaro Revive relied on scientific knowledge to transform its protest into a concrete and legally binding policy proposal.

In Mantaro Revive's central meeting room, across the courtyard from the lab, I conversed with Jiménez in February 2013 during our final meeting. Knowing 
that I was not a Catholic, she inquired curiously about what sustained me during times of hardship. Unimpressed by my secular answers, Jiménez informed me that she had been raised to fight for life, not just its survival, but for a "life in abundance." Resonating with the humanitarian critique of the aforementioned anthropologists, Jiménez's paraphrase of a passage from the Gospel of John (see epigraph above) condemns the state's status quo relationship to mining contamination: if no one is dying, it is not a problem. Rather than a politics of bare life, a life endured in exposure to heavy metals was intolerable; for Jiménez, her Catholic ethics obliged her to fight for an abundant life.

The thief named in this passage, who comes to "steal and slaughter and destroy," also allegorically describes the relationship between mining companies and communities. Although they are promised local economic development, many agricultural communities view mining companies as thieves of their land, leaving forever-altered landscapes in their wake. Usually only provided with the company's own environmental data, communities impacted by mining could confirm their supposedly subjective claims of dirtied streams and sick crops, livestock, and humans with Mantaro Revive's studies, leveraging them during contract renegotiations or official denunciations. The project thus emulates Jesus Christ himself. Citing perhaps the most famous line from the Gospel of John, Jiménez peered squarely over my notebook and stated matter-of-factly: "You will know the truth and the truth will set you free."

Defending an abundant life, one lived without the passive absorption of lifealtering chemicals, established Mantaro Revive's moral intention. The technocratic landscape of Peru's neoliberal governance circumscribed the medium through which the public immorality of contamination could politically enunciate its truth: science. While science served to depoliticize Mantaro Revive's politics, it also allowed the project to represent the somatic materializations of Peru's neoextractivist ethos, one which normalizes the uneven distribution of life- - "bioinequalities" (Fassin 2009, 49) — to maximize its profit. To borrow further from the anthropologist Didier Fassin (2009, 48-49), Mantaro Revive's work exemplifies a politics of life that demands more than just bare life, or life itself, but instead the biolegitimacy - a legitimacy attached to life - of a particular form of life as such, one of abundance. For Fassin (2009, 45, 49), this constitutes a biopolitics beyond the art of governing populations (Foucault 2008) to include the ethical systems that delineate which life may be made to live at the price of others. Such a politics insists that life let to die by the state, if not made to live, at least be let to live in its plenitude. 


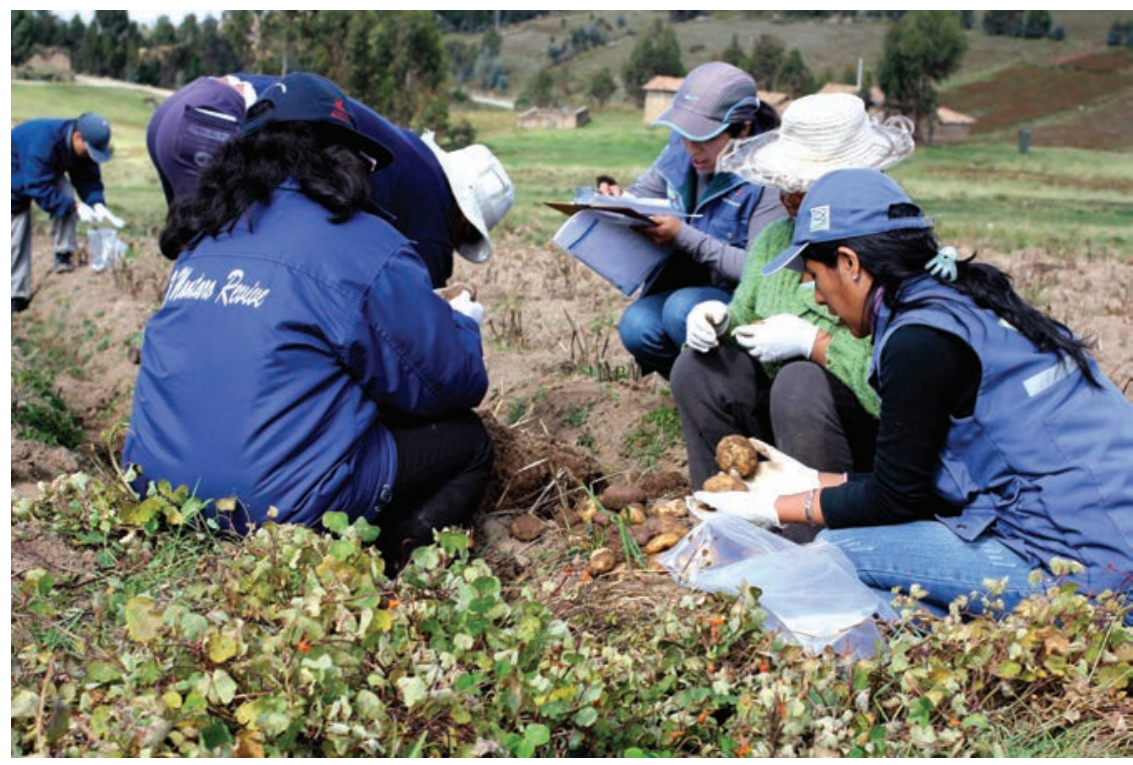

Figure 6. Members of the Mantaro Revive Project select soil samples and potatoes for heavymetal analysis. Photo by Stefanie Graeter.

Mantaro Revive's science made embodied minerals public (cf. Latour 2005; de la Cadena 2010), disrupting the given “common sense” (Rancière 2004, 304) that puts minerals into some bodies but not others, dividing the biolegitimate from the not. As I have already suggested, however, the enrollment of scientific practices by religious practitioners was not unidirectional. Scientific practices also needed the Catholic Church. Before delving further into the political implications of Mantaro Revive's work, the following detour through the project's origin story, involving the production of the 2004 lead-exposure study in La Oroya, uncovers further sociopolitical contingencies that necessitated the church as an institutional accompaniment to scientific practice.

\section{“IF JESUS WERE HERE, HE WOULD WALK WITH US": Objectivity and Jesuit Accompaniment}

In 2004, Monsignor Pedro Barreto of Huancayo visited the Jesuit Saint Louis University (SLU) in Missouri. There, he met with a then-PhD student, Felipe Sanchez, to discuss plans for an upcoming human lead-exposure study in La Oroya. At one point, Sanchez turned to the archbishop and said: "I do the science, you do the faith, and that combination will move mountains in Peru.” In turn, as they discussed their ongoing challenges, the archbishop assured him that "the stars 
are aligning" to produce what Sanchez later described to me as the first "nearly perfect" study of lead exposure in La Oroya.

The 2004 study functioned as an origin story for Mantaro Revive, and within this narrative Presbyterian minister Thomas Connor emerged as a founding father. A member of the U.S.-based missionary organization Joining Hands (known as Uniendo Manos in Peru), Connor met me in St. Louis in 2013 before attending a ten-year commemorative celebration for the organization's work in La Oroya. As we enjoyed a short respite from the summer heat inside a Subway restaurant, Connor explained that his work for Joining Hands began as its "companionship facilitator" in 2003, tasked with identifying local collaborators for missionary programs that responded directly to local needs. Early on, he met Anita Gomez, the president of a small Protestant organization from La Oroya, named after Filomena Tomaira Pacsi, a female miner who perished in union struggles in the 1980s. Gomez implored him to visit her city and see environmental destruction "he wouldn't believe."

Shortly after, Connor stepped off a bus during a pit stop in La Oroya and immediately struggled to catch his breath as vapor from the air stung his lungs. This painful aerial impression compelled Connor to bring a group of fellow pastors and NGO workers to experience La Oroya's air for themselves. Deep into discussion at night during their visit, another pastor declared to the group, which included Gomez, "Brothers, just imagine if these were our kids." To this, Gomez bluntly retorted, "These are your kids, Pastor." By encouraging the group to connect themselves to La Oroya's atmosphere through U.S. offshoring of pollution onto "third-class citizens," Connor reported that Gomez engendered a "theological shift" in the group. Their shared respirations activated what Tim Choy (2015) describes as the capacity of air to make fellow-breathers "con-spire" around commitments that challenge uneven geographies of breath. Before long, Connor had made La Oroya a central project of Joining Hands.

As Connor began consulting with locals, a group of teachers informed him that the city lacked impartial scientific data; the company still claimed that the chimney's gaseous plumes were just water vapor. This was not for lack of studies. The MINSA study had documented high lead levels back in 1999 and other research soon followed. People mistrusted these studies, however, because of potential corruption or technical inadequacies, such that the smelter's plumes remained water vapor, despite respiratory evidence to the contrary. Perhaps a new study was in order. The Centers for Disease Control and Prevention (CDC) informed Connor that a proper lead study would cost upward of half a million 
dollars, well beyond his budget and technical expertise. Luckily, Joining Hands's U.S. contingent had also taken a particular interest in La Oroya on learning that Doe Run operated a sister smelter right outside of St. Louis. They located Felipe Sanchez, who had previously studied a nearby Doe Run superfund site, and he accepted their request to join the venture after hearing members of Filomena assert that "science was needed for a political fight."

The epidemiological knowledge of Sanchez, now a policy studies professor at SLU, quickly reshaped their plans. In an interview on the SLU campus in 2013, he explained to me that residents originally requested he replicate MINSA's fiftychild study, mistrusted because of fears that the public institution was "in the pockets of the company." Aside from potential corruption, MINSA's study also lacked scientific rigor. For the political sway they desired, Sanchez insisted, they needed an epidemiological "gold standard" study: a comparative human exposure assessment between a study population (La Oroya) and a control (Concepción) to statistically represent lead exposure among the city's thirty-three thousand residents.

As the study's technical dimensions made headway, Joining Hands felt the tide of community support turn against it in La Oroya. As other NGOs had warned Connor, the city was often too "beholden to the company" for outside groups to gain any traction. Around this time, in July of 2004, word arrived of Pope John Paul II's appointment of Pedro Barreto as Huancayo's archbishop, whose archdiocese included La Oroya. Sensing the potential for a powerful alliance, Connor and Gomez invited him to visit La Oroya and, surprisingly, he came to see them after only three days in office. In Connor's retelling, when the nervewracking meeting began, Gomez greeted Barreto as "brother" (hermano). Both informal and unorthodox, the greeting also pegged her immediately as an evangelical. But Barreto appeared unfazed and Gomez continued: "Hermano, if Jesus were here, he would walk with us. Will you walk with us?" The archbishop "paused, he got tears in his eyes, and said, 'hermana [sister], I will walk with you and the Church will walk with you." Himself choked up, Connor recalled the significance of the archbishop's commitment: "We knew we didn't have legitimacy and the company had succeeded in painting us as radicals, as foreigners, as environmentalists - ambientalistas, which is an insult - and then el radical [radicals], connected with Sendero . . . and so [the company] had succeeded, with just a few articles, in delegitimizing the movement and we needed the Catholic Church desperately." 
Barreto's symbolic gesture to cross interfaith lines and, in imitation of Christ, to walk with them, revived the movement's social legitimacy. Barreto became the public face and mouthpiece of the study, soon appearing in many newspapers and television broadcasts. Behind the scenes, his presence also enabled practical interventions, such as the approval of visas for SLU scientists and other U.S. volunteers. As a Jesuit archbishop, he also helped Sanchez convince SLU's administration to contribute monetary support. Critically, when local health bureaucrats delayed signing the study's human subjects protocol, likely offended by its implication of their own negligence, Barreto went door to door imploring them to sign. In La Oroya, he dispelled rumors planted by the company that “foreign vampires" were coming to steal their children's blood and helped with the gargantuan task of recruiting 250 participants despite continuous intimidation tactics by company supporters. After three stressful days of collecting blood samples and guarding them at night, Sanchez successfully sent them to the CDC lab in Atlanta for analysis, all as planned.

The study's results held no surprises: Oroyan residents had exceedingly high blood lead levels (Universidad de San Luis 2005). As Sanchez promised, however, its results have remained undeniable, as though carrying papal infallibility itself. The SLU study is by far the most cited document in policy debates, media coverage, subsequent research, and everyday discussions on La Oroya, serving as a baseline of human lead exposure in the city. While Doe Run hired consultants to reanalyze its findings — while publicly dismissing it as "just another study" - the study's reputation remained intact. As Barreto had assured Sanchez in St. Louis, the stars had improbably aligned to generate a study of near perfection.

Global health practitioners, including Paul Farmer, have promoted the Catholic notion of accompaniment, modeled after such liberation theologists as Gustavo Gutiérrez, as a method of long-term solidarity and material support to counteract impoverishment and the vulnerability to disease produced by the world's so-called structural sins (Kane 2012; Farmer and Gutiérrez 2013). Here, a diverse alliance took form — of residents, NGOs, scientists, and missionaries - held together by what Connor called a "Catholic social ethic," which "in its Latin Americanist perspective posits God as being particularly concerned for the vulnerable." Along with long-term solidarity, each accompagnateur (Farmer and Gutiérrez 2013, 183) in this network also provided what Sanchez described as a "layer of legitimacy" to their collective project. While Sanchez offered technical legitimacy and organizations from La Oroya provided a local anchor to the study's intent, the archbishop offered a layer of "ethical legitimacy" to the research. Representing 
the Catholic Church in a predominantly Catholic nation, Barreto carried institutional power that could actually contend with the power of the company and its state allies. But relatedly, by walking with the study, the archbishop conferred a moral sanctity to the motivations underlying it. His accompaniment designated the study's influences as emanating from a Christian moral position, not from monetary or personal gains, affirming its technical credibility by purifying its purpose.

Following Lorraine Daston and Peter Galison (2007, 19), objectivity can be described as a set of "virtues" or "precepts" that delineate the proper relation between a scientific subject and an object of study. Although the virtues that confer best practice have shifted through time, objectivity remains an achievement of technical veracity and belief in its faithful enactment. Science's epistemic stature within politically stable contexts can obscure this latent relation of faith between scientists and their publics. As Steven Shapin and Simon Schaffer (1985, 58-59) note, before modern science's rise to prominence, experimental scientists in midseventeenth century Europe depended on credible witnesses, esteemed for their "knowledgeability and moral constitution," to reinforce their tenuous epistemic authority. Similarly, in the divisive climate of Peruvian mining politics, a range of accompagnateurs performed participatory witnessing to engender trust in the ethics of their epistemic pursuits (cf. Choy 2011, 83-85). In particular, the moral weight of the archbishop, and of the institution he represents, generated faith in the technical achievements of the researchers he accompanied, allowing an objective study to emerge from a previous state of "epistemic murk" (Taussig 1987, 128). Even if not everyone agreed with the Catholic Church's politics or science (smelter workers continue to disparage the archbishop for threatening their livelihood), its layered ethical network nonetheless achieved a widespread public for this first groundbreaking lead-exposure study.

Earlier, I highlighted the sociopolitical grounds on which science became an efficacious tool for the Catholic Church to enact its ethos of abundant life, to do politics without Politics. Here, the origin study of Mantaro Revive elucidates how the Catholic Church became critical for producing politically actionable knowledge on contamination in the Mantaro Valley. As this retelling suggests, the greatest impediment to objective, trustworthy knowledge resulted from potential political corruption. Before concluding, I return to those on-the-ground contingencies in a region rife with suspicion of outsiders and misguided influences that shaped Mantaro Revive's years of research. 


\section{SUSPICION, SACRIFICE, AND SCIENCE IN A STATE OF CORRUPTION}

While the northern retellings of the origin study dazzled me, its miraculousness often felt incongruent with the daily toil that I observed in Peru in 2012. Scientific pursuits in the Mantaro Valley involved longitudinal ardor and sacrifice, without a miraculous outcome in sight. Earlier, I described how an ethics of abundance motivated Mantaro Revive's scientific practitioners: the truth, they maintained, promised to set them free. But even if the truth could set one free, the process of reaching it was a painful one.

“The truth hurts!" Juana Jiménez insisted during our final conversation, referring to the pain of families who learned that heavy metals laced their cows' milk and children's blood. During my fieldwork, however, it became apparent that Mantaro Revive also suffered its own pain. I heard how, years before, a purported mole had absconded with the project's funds and that office computers had also vanished. Ongoing sabotage of their research led the project's scientists to take air and water samples secretly by night to prevent companies from reducing their effluents. During fieldwork, I slept with my phone by my head awaiting calls from Jiménez; she never told me the day or time of our field expeditions in advance. When I visited Mantaro Revive's air-monitoring station in La Oroya with Melinda, I saw that the only way up to their second-floor equipment station was a rickety wooden ladder. The former staircase had mysteriously disappeared months before and acrobatic leaps were now required to download data. In February 2012, as the Congressional decision over the smelter's fate loomed, workers assaulted members of Mantaro Revive at a peaceful demonstration, and soon after, both Jiménez and the archbishop received anonymous death threats by telephone.

During my fieldwork, suspicion seemed to infiltrate all aspects of Mantaro Revive. I too struggled to establish trust, and rumors circulated that Jiménez suspected that I, as a U.S. citizen, might be a spy for Doe Run. Perhaps because of this, Mantaro Revive concealed much of the project's religious underpinnings from me, fearing, I imagine, that my future depictions could malign the project's scientific credibility. While frustrating, their distrust was not baseless: Peruvian anthropologists routinely supplement their minimal academic incomes with contract work to help companies mitigate socioenvironmental conflicts with local communities ("where the real money is," a friend and social scientist informed me). Seeming paranoia came from a very real need to protect data from theft or destruction, as well as to safeguard the confidentiality of study participants, who 


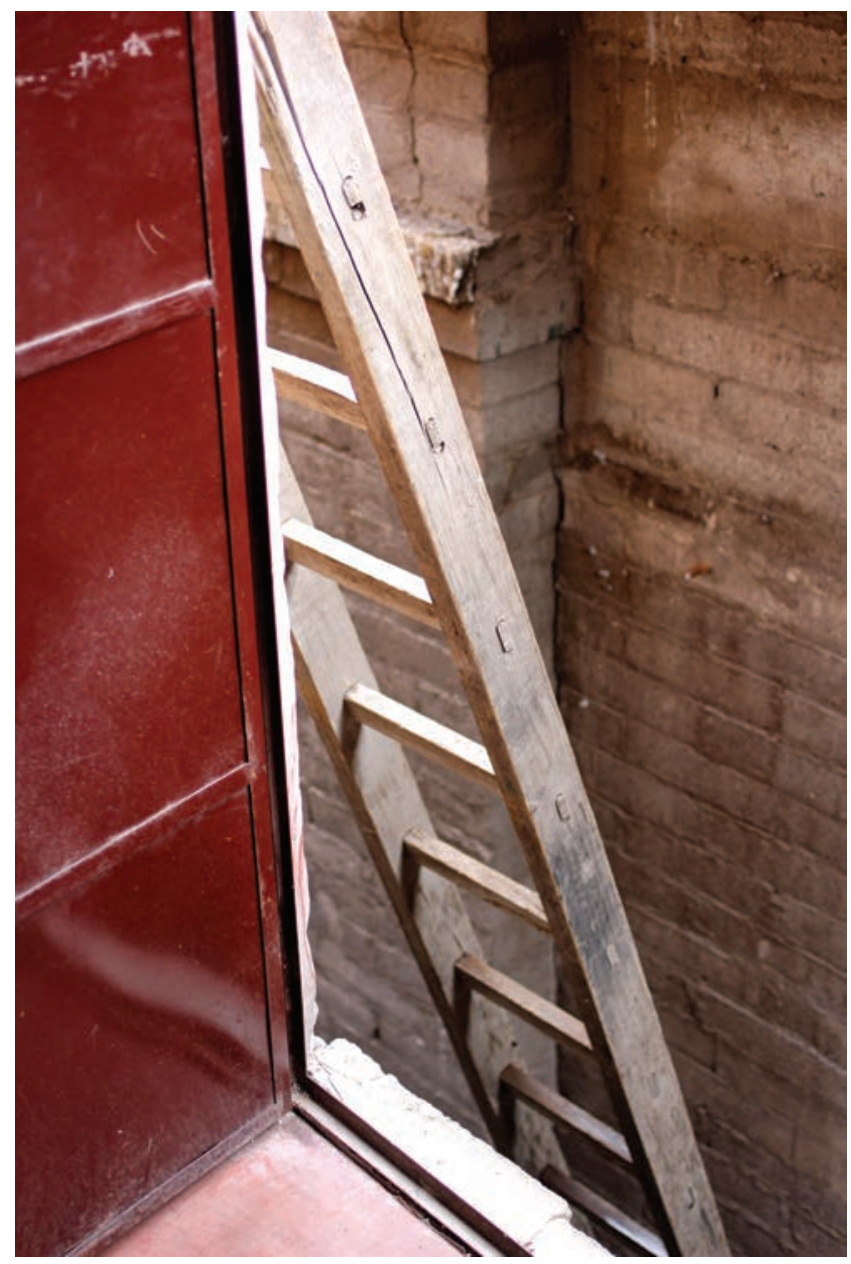

Figure 7. The ladder to the air-monitoring station in La Oroya. Photo by Stefanie Graeter.

faced serious retribution from companies, mineworkers, and product vendors should their identities be revealed.

Adding to these anxieties, financial stresses also plagued Mantaro Revive. While radio shows in La Oroya often condemned the project's enormous budget, it worked on a fraction of what a multisited, longitudinal study usually requires. Lunchtime gossip among low-rung researchers over the daily menú often bemoaned their meager or missing paychecks and the tedium of accounting for every minuscule expense. The project also lacked basic scientific instruments, such as a mechanical soil grinder used for similar research in the United States and Europe, 
which could have alleviated countless working hours from studies that always seemed to be months, or even years, behind schedule.

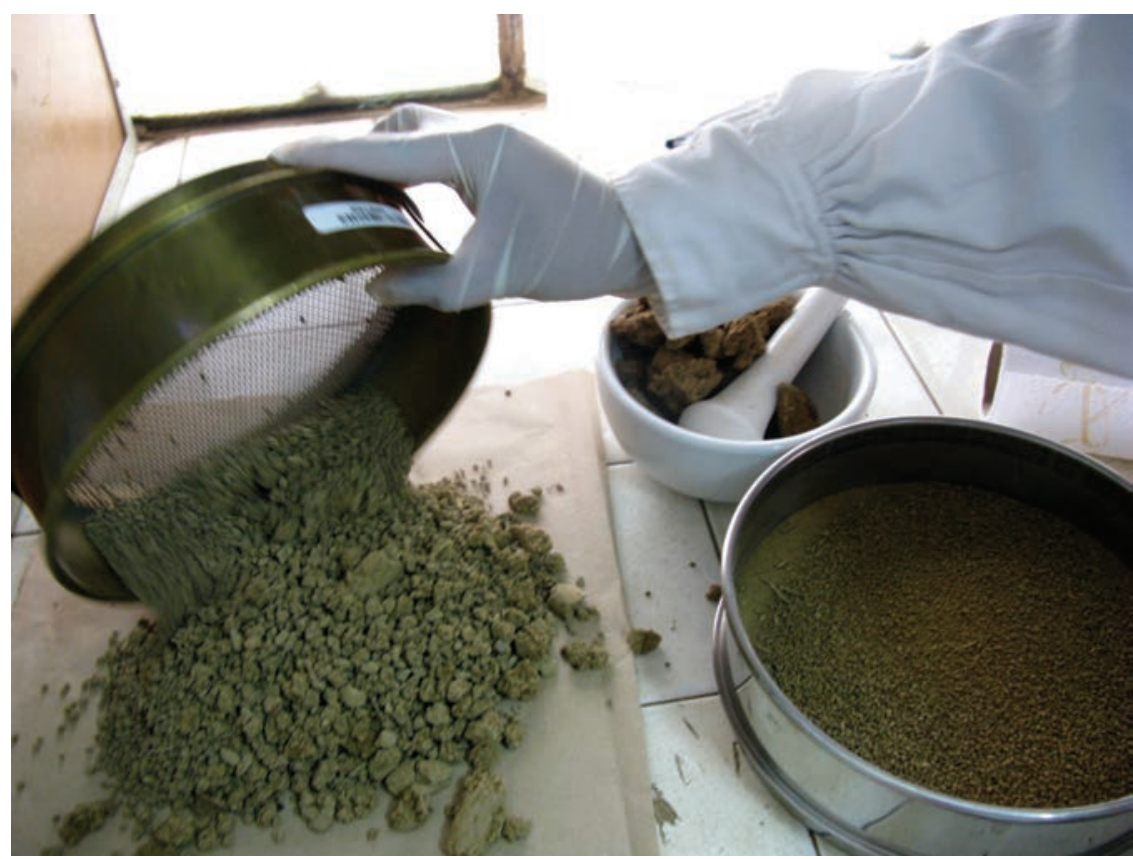

Figure 8. Preparing soil samples by hand in the Mantaro Revive laboratory. Photo by Stefanie Graeter.

A few months into my fieldwork, Sergio, a middle-aged chemist, taught me to prepare soil samples: a laborious grinding of rocky dirt with mortar and pestle, which we then scraped through finer and finer metal meshing. The process rattled my bones, and I perspired heavily under my lab coat and gas mask as my arms quickly grew weary. Sergio seemed nonetheless pleased with my progress and returned to his sample, in its final stage of grinding. Giving me a sly grin, he chuckled and said, "I have to sacrifice myself now!" and proceeded to scrape dirt reminiscent of cocoa powder through a pan of indiscernibly fine meshing. Indeed, such lab work was a sacrifice, often in a very physical sense: my attempt to complete an entire sample later that month resulted in tendinitis that lasted weeks. Yet such belt-tightening measures reflected sacrifices made intentionally by the project. Jiménez admitted that initially many regional mining companies had made generous financial offerings of support. Other Christian and secular NGOs accepted such corporate social responsibility funds to make a wide range of programs 


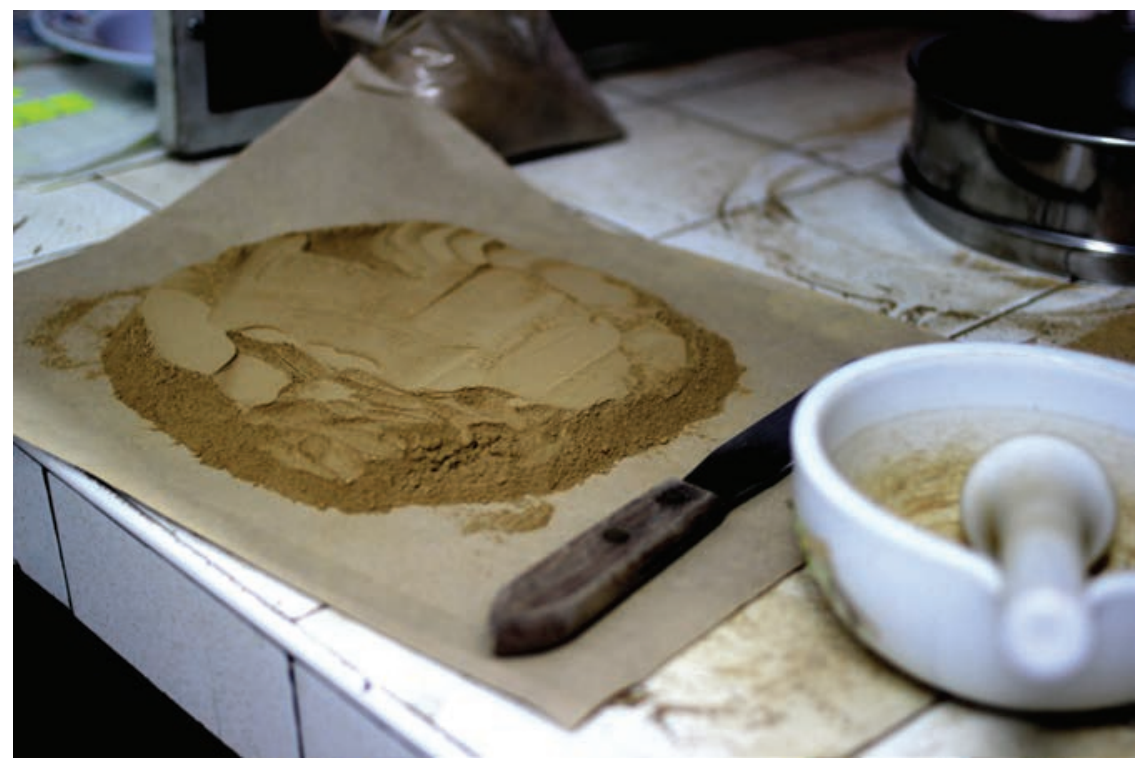

Figure 9. A finely ground soil sample. Photo by Stefanie Graeter.

possible. The money would have gone to good use for Mantaro Revive too, but would have made the project ethically and thus scientifically dubious.

In our 2013 interview, Silvio Vasquez, a sociologist and the director of the archbishop's environmental task force, implored me to consider how the lack of trust (confianza) transverses Peruvian society because of ubiquitous political corruption. I recalled immediately the near-daily newspaper headlines of elected officials ousted because of suspected financial back dealings. The same dailies contained frequent laments from cultural critics who opined that corruption tainted national politics above all else. The idioms of "traffic of influence," and also pagado, "paid off," appeared constantly during my fieldwork, as people discussed not only government and industry dysfunction but also the disingenuous interests of NGOs, local leaders, and foreign volunteers. A credible, trustworthy scientific study, according to Vasquez, could never be authored by a Peruvian institution - state, university, or industry: the fear of corruption ostensibly ran too high for Peruvian science to be fully trusted.

The scenario described by Vasquez makes the achievements of the first study all the more impressive. The longitudinal research of Mantaro Revive, however, depended entirely on the continued trust of campesino and urban communities, who donated agricultural products, natural resources, and their own bodily fluids. I heard frequent reference to the mistrust Andean communities hold against out- 
siders, no matter how benevolent their purported aims. This, of course, pertains to mining companies — who after decades or even centuries of conflict often create deep-seated mistrust with nearby communities - but it also applies to NGOs, academics, and reporters from Lima or abroad, accused of building their careers off the suffering of the poor, or, as Connor experienced, discursively linked to Sendero's legacy because of their leftist politics. Since the colonial era, external extraction of material and knowledge in the Andes has often lacked concrete benefits for locals, making research by outside groups complex and at times impossible.

Mantaro Revive's affiliation with Huancayo's archbishop in a very Catholic region facilitated relationships of trust that other environmental advocates struggled to achieve. The Catholic Church assured communities that their interests derived from a shared Christian moral position distinct from that of the economic imperatives operative in relationships with other NGOs, companies, or state institutions. These relationships of trust were not only an ethical necessity for their research but also fundamental to the procurement of samples and thus the science itself. Were Mantaro Revive to be funded by a mining company, producing the very contaminants it measured, communities would mistrust both its data and its assurances of anonymity. In such a case, the entire undertaking would have lost its purpose. "It's easy to say no," Jiménez assured me, “when your priorities are clear." So Mantaro Revive made the best of its budget, funded by an ItalianPeruvian loan forgiveness program (El Fondo Ítalo Peruano), while dirt samples continued to be ground by hand, among other inconveniences and stresses.

Such trust with communities, however, in practice required constant maintenance. Before a breathtaking chartreuse landscape of high Andean grasslands, I observed Sergio struggle to reconvince Mr. Pachari, the president of an agricultural community, to allow us to take water samples from its river. About a thirtyminute drive from La Oroya, the village stood downstream of an open-pit mine and the ruins of a Spanish foundry. Pachari expressed reluctance because he had not yet seen the results from previous samplings. The results would have helped him, he explained, during contract renegotiations with the mining company the previous month. The company had insisted that the river provided safe drinking water, despite its turbidity and the disappearance of local wildlife. The ethical protocols of Mantaro Revive's research required Pachari's participation and, like the archbishop's accompaniment, his presence distributed authorship and brought local legitimacy to the data. Sergio carefully explained that water monitoring 
required repetition to depict pollution averages across time and, eventually, $\mathrm{Pa}$ chari acquiesced and joined us to sample the river further upstream.

A few weeks later, I went on my own to interview Pachari at his office. Behind a typewriter at a large wooden desk, he expressed both gratitude and incredulity toward Mantaro Revive. While its data was his only source of information about contamination, he still had his doubts: "This is the fourth time already [taking samples], so in part this also tires us when they continue returning, returning. Or perhaps it might be that Mantaro Revive is being bribed by the money of the mine?" I asked why he suspected such a betrayal, and he explained, "In practice, there are bribes. They buy consciences in our country, in Peru." I see Pachari's suspicion resulting from Mantaro Revive's attempt to impact local, regional, and national mining politics in concert. Scaling up its data necessitated long-term evidence rather than single tests tailored to a community's particular needs. Yet Pachari's concerns about the potential of bribery also reflect the pervasive state of corruption that necessitated, shaped, and limited Mantaro Revive's work. Alone, the Catholic Church was immune to neither violence nor suspicion. Rather, the project maintained tenuous relationships of trust through ongoing ethical and epistemic practices, including sacrifices of time, safety, and pain.

\section{TO ACCOMPANY ANOTHER WORLD}

Extractive histories, a state of corruption, and an ethos of abundance shaped the articulations of Catholic science in the Mantaro Valley. The epistemic demands of Peruvian mining politics obliged technoscientific evidence derived from normative methodology and expressions of expertise, but also the choreography of a specific constellation of practitioners and practices, to ensure incorruptibility. These are situated relations of objectivity, not quite what Donna Haraway (1988, 590) called for in her classic text on situated knowledges, in which novel forms of objectivity presage "better accounts of the world." Mantaro Revive did not subvert the technical hegemony of neoextractivist governance, but used standard laboratory conditions and sampling methods to enact its ethics, while remaining able to act politically. Yet in a state of corruption, not only standard technical methods of objectivity mattered, but also societal faith that such principles would actually be enacted.

Through practices of accompaniment, both physical and symbolic, Mantaro Revive gathered ecclesiastical, scientific, and local signatories - a synergy of expertise and ethics - to index the credibility of its research and the fidelity of its facts. Mantaro Revive's ethics, however, also generated the basic preconditions 
for the research itself. Morally compelled by a life of abundance, it generated the impetus for rigorous longitudinal heavy-metal monitoring and sacrificial forms of care to conduct research under often less-than-ideal social and technical circumstances. Isabelle Stengers (2010, 54-55) describes such internal and external epistemic conditions as an "ecology of practices." For Stengers, knowledge practices (not just scientific ones) form through ecologies of materially delineated "requirements" and socially configured "obligations" that constitute conditions of "best practices." Ethnographically reassembling ecologies of practices evinces the relations that constrain and engender socially legitimate, politically actionable knowledge. Such a task, I contend, is critical for further anthropological inquiry into diverse ecopolitical projects that seek to subvert a future defined by the ethics of extractive capitalisms and their unevenly felt anthropogenic aftermaths.

Political actionability, the ability to act politically, is not an end in itself. The abundant future envisioned by Mantaro Revive continues to unfold within a mixture of political achievements and setbacks. In 2012, under increasing pressure from environmental and human rights advocates (applying the data from Mantaro Revive's studies, among others), the Peruvian government and Doe Run's other creditors liquidated the company, installing a temporary administration as they prepared to sell the smelter. Later in 2012, Mantaro Revive's research and advocacy contributed to the creation of the first major health ordinance directed at mitigating heavy-metal exposure in the Junín region. Although it remained unclear how or whether anyone would comply with the law, Jiménez saw this as a positive step forward.

These achievements, however, must be considered alongside other economic and political developments in Peru. When I departed in 2013, Doe Run had ratcheted up its case against Peru's government in an international arbitration court, demanding $\$ 800$ million for a purported breach of the United States-Peru Trade Agreement (Martin 2013). When global mineral prices fell in 2014, panic grew that the nation's recent economic growth might lose momentum. This led to new policies to increase foreign investment by relaxing timelines for adherence to, and penalties for noncompliance with, Peru's environmental laws (Republica 2014). In July 2016, the Peruvian state defeated Doe Run in court, but without a new buyer for La Oroya's smelter, workers have decided to stand behind further rollbacks of environmental standards to make its purchase more economically profitable. The newly appointed neoliberal President Pedro Kuszynski appears to share such aspirations. Kuszynski recently argued that the smelter's capacity to process so-called dirty copper for the nearby Chinese-owned Toromocho mine, 


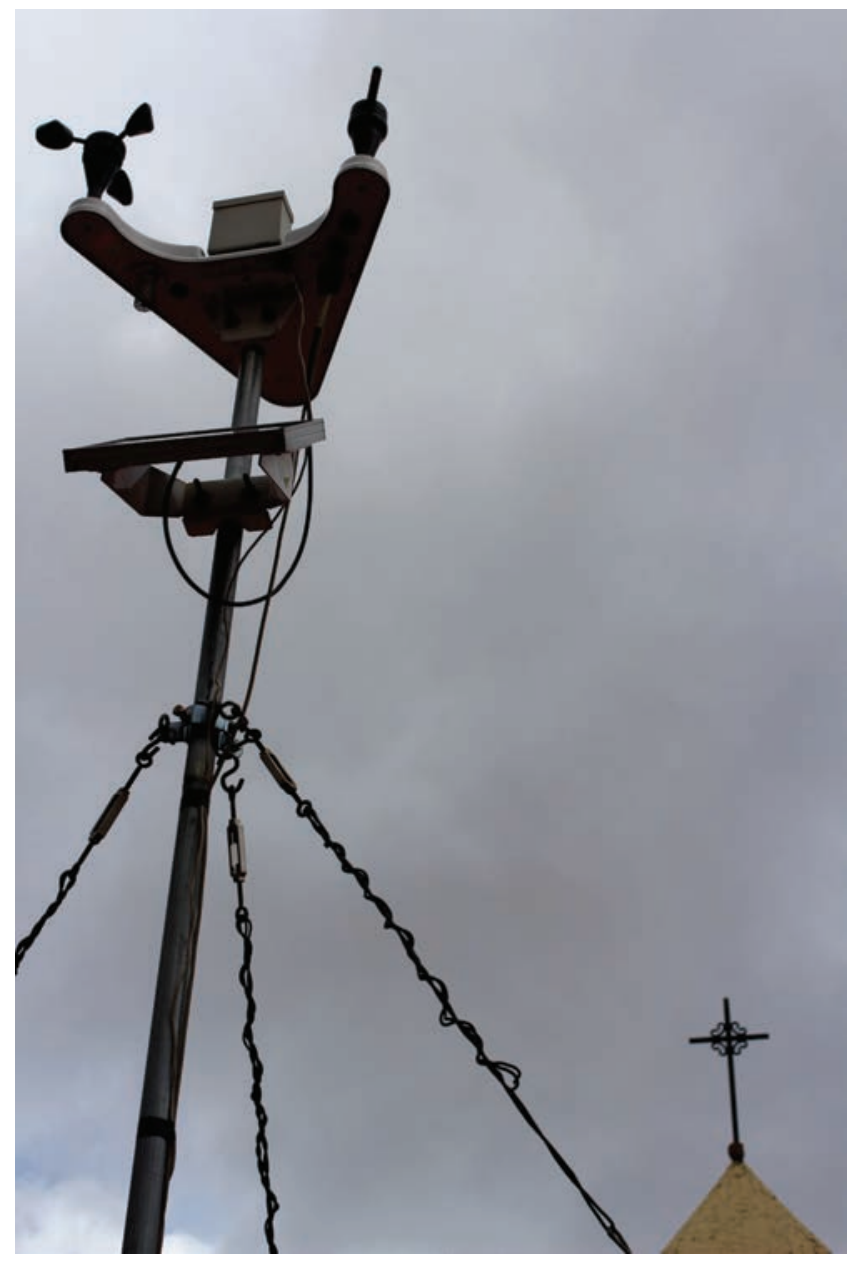

Figure 10. Air monitoring equipment in La Oroya. Photo by Stefanie Graeter.

which produces copper too high in arsenic to smelt in China (but not in Peru), warranted an extension of the company's liquidation timeline (Reuters 2016). Such developments foreclose certain political possibilities, but Pope Francis's recent ecologically driven encyclical may portend novel potentials for Catholic practices of accompaniment within future iterations of Peruvian neoextractivist politics.

While ultimately contending with uneven and shifting global, national, and local distributions of power, Mantaro Revive's work cannot be reduced to what limits it. Unlike the biological citizens described by Adriana Petryna (2002), Mantaro Revive's exposure science does not serve as a means of access to existing benefits of citizenry. Instead, its work enacts conditions of citizenship and de- 
mocracy that do not yet function or even exist. To repeat the argument of Didier Fassin $(2009$, 49), contemporary societies are defined not only by biopowerthe power over life, as described by Foucault — but also by battles of biolegitimacy, "the power of life as such." The ubiquitous exposure of life to heavy metals in the Mantaro Valley constitutes one such manifestation of unlegitimized life, let to die without vital possibilities of abundance. Mantaro Revive's scientific evidence of mineral enfleshments exposed one such form of sacrificed, unlegitimized life.

Through science and policy, Mantaro Revive demanded biolegitimacy for those denied it, speaking in the name of rights and legal protections for those whom the law does not represent. Jacques Rancière (2004, 302) paradoxically describes such rights of man as "the rights of those who have not the rights that they have and have the rights that they have not." For Rancière (2004, 304), the enactment of rights by subjects for whom rights are denied constitutes a political subjectivization he calls dissensus: "They not only confront the inscriptions of rights to situations of denial; they put together the world where those rights are valid and the world where they are not." In short, they live rights within a social world in which these rights are not rights. Obliged by an ethos of abundance, Mantaro Revive's practices scientifically proved the breach of laws - and generated new ones - within a country in which no one complies with the law. They accompany a world that still awaits its making.

\begin{abstract}
Since the turn of the twenty-first century, the rapid growth of Peru's extractive industries has unleashed diverse forms of political resistance to an economic system dependent on ecological destruction and human harm. In the central highlands of Peru, a Catholic scientific project based out of the Archdiocese of Huancayo undertook six years of research on heavy-metal contamination in the Mantaro Valley. This included lead-exposure studies in the notoriously polluted city of La Oroya, home to the country's largest polymetallic smelter. How did the Catholic Church become an apt institution for the production of science in this region? Drawing on fieldwork with the Revive the Mantaro Project, this article conceptualizes the integration of religious and scientific practitioners and practices and the political landscape that necessitated, shaped, and limited them. Technocratic governance and anti-leftist sentiments made science a suitable political idiom for the Catholic Church to enact its ethos of abundance and demand the legitimacy of life beyond bare life. A state of endemic corruption and epistemic mistrust also obliged Catholic accompaniment to scientific practices to generate trust for the researchers and to provide ethical credibility as their knowledge entered the fray of national mining politics. Ultimately contending with entrenched systems of power, the Revive the Mantaro Project's significance ex-
\end{abstract}


tended beyond political efficacy; its practices enacted a world of democracy, rights, and legal protections not yet of this world. [science; Catholicism; mining politics; toxicity; neoextractivism; abundance; objectivity; biolegitimacy; accompaniment; Peruvian Andes]

\section{NOTES}

Acknowledgments Many individuals accompany this article. I am grateful for the teachings, patience, and generosity of members and participants of the Proyecto Mantaro Revive, the Arzobispado de Huancayo, and Joining Hands. During research, I drew insight and support from Letizia Arneodo, Marcela Artica Martínez, Nadia Meza Cantalicio, and Roberto Tigani. Along with three anonymous reviewers, many colleagues provided close readings and valuable contributions to drafts of the article. I would especially like to thank Patricia Alvarez Astacio, Tim Choy, Michael D’Arcy, Marisol de la Cadena, Joseph Dumit, Mariel García Llorens, Cristiana Giordano, Rima Praspaliauskiene, and Jerry Zee for helping to shape this text. I also received important feedback from presenting this article to the Program in Science and Technology Studies at the University of California, Davis; Alan Klima's 2014 writing seminar; the University of California Humanities Research Institute's Humanities Studio on Regulating Sex/ Religion; and the Science in Human Culture program at Northwestern University. My research was funded by the National Science Foundation, the Social Science Research Council, and the American Council of Learned Societies.

1. Throughout the text I refer to the group of people and practices that composed the Mantaro Revive Project as a project, and intentionally avoid the terminology of organization or NGO. Project was the preferred terminology of Mantaro Revive's organizers, who frequently emphasized that while an organization preexists its projects and practices, the project of Mantaro Revive existed as a direct response to the needs of civil society. This distinction between a project and organization also became important for their attempts to distance themselves from the much-maligned environmental NGOs operating in the same region.

2. Scientific study of the material world has a long, complex relationship to Christianity and Catholicism, describable as neither one of "harmony" nor of "conflict" (Lindberg and Numbers 1986, 6). Arising alongside Puritanism and its renewed attention to the earthly realm, a "secular theology" (Funkenstein 1986, 3) began in seventeenth-century Europe as laymen usurped the Catholic Church's epistemic terrain and control of education. While early histories of science depicted the ensuing relationship between the church and modern science as warfare, more recent research has produced nuanced portrayals of an interaction both complementary and conflictual (Lindberg and Numbers 1986). For instance, when the viceroy put Europe's famous pedagogues, the Jesuits, to work as missionaries in Latin America, they also produced scientific knowledge resulting from their long-term interaction with indigenous individuals. Science provided these Jesuits with a means of survival in unfamiliar terrain, while also supporting evangelization efforts by converting shamanic traditions into medical knowledge (Prieto 2011). Today, the Argentinian Pope Francis, a former chemist himself, supports climate change science (see laudatosi.com), but the Catholic Church's stance on the sanctity of life also places it in opposition to reproductive and population science, even though Catholics themselves may incorporate both spiritual and technological assistance to human reproduction, as the anthropologist Elizabeth Roberts (2012) documents based on research in Ecuador.

3. In Andean cosmology, Apus are powerful tirakuna or earth beings (see de la Cadena 2015, xxiii), nonhuman entities that are also mountains. Apu is also sometimes translated as mountain god or spirit.

4. La Defensoría del Pueblo (literally, the "Defender of the People") is an autonomous institution of the Peruvian state designed to protect the rights of citizens. 


\section{REFERENCES}

Agamben, Giorgio

1998 Homo Sacer: Sovereign Power and Bare Life. Translated by Daniel Heller-Roazen. Stanford, Calif.: Stanford University Press. Originally published in 1995.

Asad, Talal

2003 Formations of the Secular: Christianity, Islam, Modernity. Stanford, Calif.: Stanford University Press.

Auyero, Javier, and Debora Swistun

2007 "Confused Because Exposed: Towards an Ethnography of Environmental Suffering." Ethnography 8, no. 2: 123-44. https://doi.org/10.1177/ 1466138107078630 .

Bebbington, Anthony, Leonith Hinojosa, Denise Humphreys Bebbington, Maria Luisa

Burneo, and Ximena Warnaars

2008 "Contention and Ambiguity: Mining and the Possibilities of Development." Development and Change 39, Forum 2008: 887-914. https://doi.org/10.1111/ j.1467-7660.2008.00517.x.

Brown, Phil

1992 "Popular Epidemiology and Toxic Waste Contamination: Lay and Professional Ways of Knowing." Journal of Health and Social Behavior 33, no. 3: 267-81.

Callison, Candis http://www.jstor.org/stable/2137356.

2014 How Climate Change Comes to Matter: The Communal Life of Facts. Durham, N.C.: Duke University Press.

Choy, Timothy

2011 Ecologies of Comparison: An Ethnography of Endangerment in Hong Kong. Durham, N.C.: Duke University Press.

2015 "Drawing Breath Together, Tending to Suspension: Sketches for an Atmospheric Conspiracy." Paper presented at the Engineered Worlds conference, University of Chicago, Chicago, Ill., October 2-3.

Daston, Lorraine J., and Peter Galison

2007 Objectivity. New York: Zone Books.

de la Cadena, Marisol

2010 "Indigenous Cosmopolitics in the Andes: Conceptual Reflections beyond 'Politics." Cultural Anthropology 25, no. 2: 334-70. https://doi.org/10.1111/ j.1548-1360.2010.01061.x.

2015 Earth Beings: Ecologies of Practice across Andean Worlds. Durham, N.C.: Duke University Press.

Defensoría del Pueblo

2016 "Decimonoveno informe anual de la Defensoría del Pueblo, Enero-Diciembre 2005." Lima: Defensoría del Pueblo. http://www.defensoria.gob.pe/informes-

Fassin, Didier publicaciones.php.

2009 "Another Politics of Life is Possible." Theory, Culture, and Society 26, no. 5: 44 60. https://doi.org/10.1177/0263276409106349.

Fortun, Kim

2001 Advocacy after Bhopal: Environmentalism, Disaster, New Global Orders. Chicago: University of Chicago Press.

Foucault, Michel

2003 "Society Must Be Defended": Lectures at the Collège de France, 1975-1976. Translated by David Macey. New York: Picador. Originally published in 1997.

2008 The Birth of Biopolitics: Lectures at the Collège de France, 1978-1979. Translated by Graham Burchell. New York: Palgrave Macmillan. Originally published in 2004. 
Farmer, Paul, and Gustavo Gutiérrez

2013 In the Company of the Poor: Conversations with Dr. Paul Farmer and Fr. Gustavo Gutiérrez. Edited by Michael Griffin and Jennie Weiss Block. Maryknoll, N.Y.: Orbis Books.

Ferguson, James

1994 The Anti-Politics Machine: "Development," Depoliticization, and Bureaucratic Power in Lesotho. Minneapolis: University of Minnesota Press.

Funkenstein, Amos

1986 Theology and the Scientific Imagination from the Middle Ages to the Seventeenth Century. Princeton, N.J.: Princeton University Press.

Gudynas, Eduardo

2012 "Estado compensador y nuevos extractivismos: Las ambivalencias del progresismo sudamericano.” Nueva Sociedad, no. 237: 128-46. http://nuso.org/ articulo/estado-compensador-y-nuevos-extractivismos-las-ambivalencias-delprogresismo-sudamericano.

2014 "Sustentación, aceptación, y legitimación de los extractivismos: Múltiples expresiones pero un mismo basamento.” Revista Opera, no. 14: 137-59. http://

Gutiérrez, Gustavo www.redalyc.org/articulo.oa?id $=67540024007$.

1988 A Theology of Liberation: History, Politics, and Salvation. Translated by Sister Caridad Inda and John Eagleson. Maryknoll, N.Y.: Orbis Books. Originally published in 1973.

Haraway, Donna

1988 "Situated Knowledges: The Science Question in Feminism and the Privilege of Partial Perspective." Feminist Studies 14, no. 3: 575-99. https://doi.org/ $10.2307 / 3178066$

Kane, George

2012 "Breaking Bread Together: The Convergent Development of Accompaniment in Catholic Secular Global Health Efforts.” Journal of Global Health Perspectives, August 1. http://jglobalhealth.org/article/breaking-bread-together-theconvergent-development-of-accompaniment-in-catholic-and-secular-globalheath-efforts.

Kirsch, Stuart

2014 Mining Capitalism: The Relationship between Corporations and their Critics. Berkeley: University of California Press.

Latour, Bruno

2005 "From Realpolitik to Dingpolitik, or How to Make Things Public." In Making Things Public: Atmospheres of Democracy, edited by Bruno Latour and Peter Weibel, 14 41. Cambridge, Mass.: MIT Press.

Li, Fabiana

2015 Unearthing Conflict: Corporate Mining, Activism, and Expertise in Peru. Durham, N.C.: Duke University Press.

Lindberg, David C., and Ronald L. Numbers

1986 "Introduction." In God and Nature: Historical Essays on the Encounter between Christianity and Science, edited by David C. Lindberg and Ronald L. Numbers, 1-18. Berkeley: University of California Press.

Lora-Wainwright, Anna

2013 "The Inadequate Life: Rural Industrial Pollution and Lay Epidemiology in China."

Lyons, Kristina China Quarterly 214: 302-20. https://doi.org/10.1017/S0305741013000349.

2008 "Emergent Forms of Death Warning: Highly Toxic Experiments." Pensamiento Jurídico, no. 22: 95-133. http://www.revistas.unal.edu.co/index.php/peju/ article/view/38172. 
2016 "Decomposition as Life Politics: Soils, Selva, and Small Farmers under the Gun of the U.S.-Colombian War on Drugs." Cultural Anthropology 31, no. 1: 56-81. https://doi.org/10.14506/ca31.1.04.

Mallon, Florencia E.

1983 The Defense of Community in Peru's Central Highlands: Peasant Struggle and Capitalist Transition, 1860-1940. Princeton, N.J.: Princeton University Press.

Mantaro Revive

2007 "Avances de resultados de la evaluación de calidad ambiental de los recursos Martin, Andrew agua y suelo.” Huancayo, Peru: Caritas Arquidiocesana de Huancayo.

2013 “Coup d'Etat to Trade Seen in Billionaire Toxic Lead Fight." Bloomberg, May 10. http://www.bloomberg.com/news/articles/2013-05-09/rennert-800-

Murphy, Michelle million-toxic-lead-fight-roils-global-trade.

2006 Sick Building Syndrome and the Problem of Uncertainty: Environmental Politics, Technoscience, and Women Workers. Durham, N.C.: Duke University Press.

Nash, June

1979 We Eat the Mines and the Mines Eat Us: Dependency and Exploitation in Bolivian Tin Mines. New York: Columbia University Press.

Nguyen, Vinh-Kim

2004 “Antiretroviral Globalism, Biopolitics, and Therapeutic Citizenship." In Global Assemblages: Technology, Politics, and Ethics as Anthropological Problems, edited by Aihwa Ong and Stephen J. Collier, 124 44. Malden, Mass.: Blackwell.

Petryna, Adriana

2002 Life Exposed: Biological Citizens after Chernobyl. Princeton, N.J.: Princeton University Press.

Prieto, Andrés I.

2011 Missionary Scientists: Jesuit Science in Spanish South America, 1570-1810. Nashville, Tenn.: Vanderbilt University Press.

Rancière, Jacques

2004 "Who is the Subject of the Rights of Man?" South Atlantic Quarterly 103, nos. 23: 297-310. https://doi.org/10.1215/00382876-103-2-3-297.

Redfield, Peter

2005 “Doctors, Borders, and Life in Crisis." Cultural Anthropology 20, no. 3: 328-61. https://doi.org/10.1525/can.2005.20.3.328.

Republica

2011 “El boom a fondo.” November 27. http:/ / larepublica.pe/27-11-2011/el-boomfondo.

2014 "Comisión Permanente aprobó 'paquetazo ambiental' para reactivar la economía.” July 3. http://larepublica.pe/03-07-2014/comision-permanentereanudara-debate-sobre-paquetazo-economico-para-reactivar-la-economia.

Reuters

2016 "Peru Smelter May Process Copper with High Arsenic Content-." August 5. http: / /www.reuters.com/article/peru-copper-idUSL1N1AM1LA.

Roberts, Elizabeth F. S.

2012 God's Laboratory: Assisted Reproduction in the Andes. Berkeley: University of California Press.

Sawyer, Suzana

2004 Crude Chronicles: Indigenous Politics, Multinational Oil, and Neoliberalism in Ecuador. Durham, N.C.: Duke University Press.

Schulte-Bockholt, Alfredo

2013 Corruption as Power: Criminal Governance in Peru during the Fujimori Era (1990-2000).

Bern: Peter Lang. 
Shapin, Steven, and Simon Schaffer

1985 Leviathan and the Air-Pump: Hobbes, Boyle, and the Experimental Life. Princeton, N.J.: Princeton University Press.

Shapiro, Nicholas

2015 "Attuning to the Chemosphere: Domestic Formaldehyde, Bodily Reasoning, and the Chemical Sublime.” Cultural Anthropology 30, no. 3: 369-93. https://doi.

Stengers, Isabelle org/10.14506/ca30.3.02.

2010 Cosmopolitics, I. Translated by Robert Bononno. Minneapolis: University of Minnesota Press. Originally published in 2003.

Stensrud, Astrid B.

2016 "Climate Change, Water Practices, and Relational Worlds in the Andes." Ethnos 81, no. 1: 75-98. https://doi.org/10.1080/00141844.2014.929597.

Svampa, Maristella

2015 "Commodities Consensus: Neoextractivism and Enclosure of the Commons in Latin America." South Atlantic Quarterly 114, no. 1: 65-82. https://doi.org/ 10.1215/00382876-2831290.

Taussig, Michael

1980 The Devil and Commodity Fetishism in South America. Chapel Hill: University of North Carolina Press.

1987 Shamanism, Colonialism, and the Wild Man: A Study in Terror and Healing. Chicago:

Ticktin, Miriam University of Chicago Press.

2006 "Where Ethics and Politics Meet: The Violence of Humanitarianism in France." American Ethnologist 33, no. 1: 33-49. https://doi.org/10.1525/ae.2006.33. 1.33.

Universidad de San Luis

2005 "Estudio sobre la contaminación ambiental en los hogares de La Oroya y Concepción y sus efectos en la salud de sus residentes." http://www.aidaamericas.org/es/estudio-sobre-la-contaminacion-ambiental-en-los-hogares-dela-oroya-y-concepcion-y-sus-efectos-en-la.

Villena Chávez, Jorge

1999 "Estudio de plomo en sangre en un población seleccionada de La Oroya." Lima: MINSA/DIGESA.

Welker, Marina

2009 “'Corporate security begins in the community': Mining, the Corporate Social Responsibility Industry, and Environmental Advocacy in Indonesia.” Cultural Anthropology 24, no. 1: 142-79. https://doi.org/10.1111/j.1548-1360.2009. 00029.x.

2014 Enacting the Corporation: An American Mining Firm in Post-Authoritarian Indonesia. Berkeley: University of California Press. 